Western University Scholarship@Western

Aboriginal Policy Research Consortium International (APRCi)

2000

\title{
White Aborigines: Identity politics in Australian art
}

Fiona Nicoll

Follow this and additional works at: https://ir.lib.uwo.ca/aprci

Part of the Australian Studies Commons, and the Other Sociology Commons

Citation of this paper:

Nicoll, Fiona, "White Aborigines: Identity politics in Australian art" (2000). Aboriginal Policy Research Consortium International (APRCi). 312.

https://ir.lib.uwo.ca/aprci/312 
This article was downloaded by: [University of Western Ontario]

On: 16 December 2012, At: 07:39

Publisher: Routledge

Informa Ltd Registered in England and Wales Registered Number:

1072954 Registered office: Mortimer House, 37-41 Mortimer Street, London W1T 3J H, UK

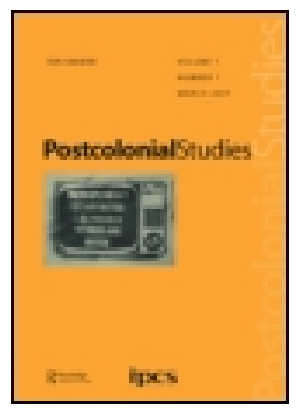

\section{Postcolonial Studies}

Publication details, including instructions for authors and subscription information:

http:// www. tandfonline.com/loi/ cpcs20

\section{White Aborigines: Identity politics in Australian art}

Fiona Nicoll

Version of record first published: 19 Aug 2010.

To cite this article: Fiona Nicoll (2000): White Aborigines: Identity politics in Australian art, Postcolonial Studies, 3:1, 111-117

To link to this article: http:// dx. doi. org/ 10.1080/ 13688790050001417

\section{PLEASE SCROLL DOWN FOR ARTICLE}

Full terms and conditions of use: http://www.tandfonline.com/page/ terms-and-conditions

This article may be used for research, teaching, and private study purposes. Any substantial or systematic reproduction, redistribution, reselling, loan, sub-licensing, systematic supply, or distribution in any form to anyone is expressly forbidden.

The publisher does not give any warranty express or implied or make any representation that the contents will be complete or accurate or up to date. The accuracy of any instructions, formulae, and drug doses should be independently verified with primary sources. The publisher shall not be liable for any loss, actions, claims, proceedings, demand, or costs or damages whatsoever or howsoever caused arising directly or indirectly in connection with or arising out of the use of this material. 


\title{
White Aborigines: identity politics in Australian art
}

\author{
FIONA NICOLL
}

\section{Ian McLean \\ White Aborigines: Identity Politics in Australian Art \\ Melbourne: Cambridge University Press \\ 204 pp, ISBN 0521584167 (hb), AU\$39.95.}

The value of this book lies in its ambitious theoretical scope and the important questions it asks about the status of Aboriginality within Australian art. Suggesting that 'perhaps the history of non-Aboriginal Australian painting exposes, in its upturning and reinvention of a Western identity in the antipodes, the very structures of semiological exchange which stage identity' ( $p$ 7), Ian McLean's analysis of the figure of the 'White Aborigine' in Australian art aims to deliver insights into deeper processes of European identity-formation. While it does forge an original thematic path through Australian art history and theory, however, White Aborigines ultimately fails to achieve its aims-not least, perhaps, because its psychoanalytic bias prevents alternative interpretations of identity politics from surfacing in the narrative.

McLean's narrative is organised around three tropes: melancholy, redemption and reconciliation. Melancholy and the search for redemption shape a sensibility that explains (even if it fails to justify) the barbarity of Australian colonialism. And reconciliation is used to figure the possibility of a postcolonial present-future.

McLean embarks on his historical survey with an engaging discussion of the melancholic underbelly of the European Enlightenment. He writes: 'Melancholy was the diagnosis, colonialism the medicine, utopia the body redeemed' (p 22). So, while the expulsion of convicts and other undesirables promised to simultaneously redeem Europe and reform its exiles, it also rendered Australia 'a primary site of melancholy' ( $p$ 22). McLean then traces melancholy through three colonial aesthetic conventions: the sublime, the grotesque and the picturesque. These are, in turn, respectively, connected to the colonial 'phases' of exploration, invasion and settlement.

Overall McLean's discussion of colonial art in the second and third chapters remains unconvincing. I am troubled by the working distinction that he maintains between 'colonialism', on the one hand, and 'invasion', on the other hand. Only the 'grotesque' depictions of Aborigines by Thomas Watling and the 
Port Jackson painter qualify as the art of 'invasion'. The, surveyor-artist, Thomas Mitchell, is positioned at 'the vanguard of the frontier prior to invasion' ( $\mathrm{p}$ 38). This is in spite of Mitchell's murderous treatment of Aborigines unfortunate enough to have crossed his path. And we are told that the "picturesque' painter John Glover 'settled in Tasmania in the wake of invasion' (p 38). This presentation of invasion as a distinct phase of the colonial project mutes the gunshots that broke the sublime silence of the surveying party and shattered the serenity of the settler's picturesque garden. And it obscures the important point that, from the perspective of indigenous Australians, invasion has never ceased.

Moreover, while it might work as an abstract schema, the superimposition of the melancholy-redemption dialectic upon the couplings of sublime-exploration/ grotesque-invasion/picturesque-settlement produces confusion when applied to the heterogeneous archive of colonial art. For example, McLean writes: 'If the invasion of Australia initially had need of a grotesque aesthetic, its ultimate aim was redemption ... For most of the nineteenth century this redeeming vision was imagined by painters in terms of the picturesque' ( $p$ 35). He goes on to say, however, that the picturesque ultimately fails in Australia-in part because it is haunted by the melancholy memory of indigenous genocide. He continues, '... the desire for redemption is a strong tonic. One explorer determined to discover the picturesque and the sublime in Australia was [the surveyor-artist] Thomas Mitchell' ( $p$ 37). Terminological confusion reigns by the end of chapter three when the explorer-artist Thomas Baines is presented as a subject who finds redemption by 'render [ing] the sublime picturesque ... in a characteristic modernist fashion' ( $\mathrm{p} 47$ ).

White Aborigines then moves into a discussion that casts the 'sunny' disposition of nationalist landscape painting as an attempt to escape from the oppressive weight of colonial melancholy. McLean sees the absence of representations of Aborigines in the work of the Impressionists as 'less a disappearance than a repression, an exile to the unconscious' ( $p$ 72). Trees, nudes and itinerant workers (such as shearers) are identified as substitutes for indigenous people in Impressionist paintings. Even though he historicise s the reduction of Aborigines to signs within the fin de siecle primitivist discourse shaped partially by modernism, anthropology and psychoanalysis, McLean writes as though Freud's notion of repression is still capable of unlocking an ahistorical 'truth' about Australian race relations. For example: 'In making Aboriginality the origin and unconscious of modernity, [Baldwin] Spencer and Freud also made it the centre of modernity. The dead father, said Freud, lives on in the unconscious ... The racism of Australian nationalism ... represents a collective repression-a collective Oedipal trauma' (p 69).

One problem with this kind of reading is its failure to countenance that, at least on one level, the Impressionists were simply painting what they saw: a landscape from which Aborigines had been removed and incarcerated on missions and reserves for their 'protection'. McLean thus fails to ask two important questions. Firstly: where were the traditional owners of the lands depicted at the time these painting s were executed? And, secondly: where are the descendants of these owners today? Every time we fail to ask these questions the 
doctrine of terra nullius is subtly reinforced by the unwritten assumption that the owners of the empty lands depicted by non-indigenou s artists are always already the casualties of colonial history. ${ }^{1}$ The seriousness of how we interpret indigenous absence in cultural representations has been highlighted in recent Federal Court decisions such as the 1998 Yorta Yorta Native Title ruling, where it was determined that native title had been 'extinguished by the tide of history'.'

In his discussion of the impact of the Great War on Aboriginal representation, McLean poses an interesting question in relation to the war art of the nationalist, impressionist painter, Arthur Streeton: 'Did the war trigger memories of a long colonial war that was never spoken about, except unconsciously?' (p 80). An extract from the diaries of C. E. W. Bean (official war correspondent and historian, founder of the Australian War Memorial and creator of the Anzac myth) confirms the relevance of this line of questioning. Finding himself confined by illness to his dug-out on Gallipoli, Bean 'settled down at last to read the life and voyages of poor old Captain Cook ... If he had been told that 127 years later his barren discovery would be sending to the Mediterranean 300,000 of the best troops the British nation possesses, he might have been a little more astonished at himself for discovering it'. ${ }^{3}$ This presentation of Australia as 'barren' prior to the arrival of Cook cleared the ground for Bean's subsequent construction of the white digger as an indigenous nationalist subject. George Lambert was another war artist who executed a series of paintings depicting the 'barren' landscape of the Gallipoli peninsula. This work was a source of inspiration for the painter Hans Heysen who, McLean argues, refocussed our Oceanic angst on the central Australian desert landscape.

After introducing the first generation of 'White Aborigines' (e.g. Margaret Preston, Xavier Herbert, Katherine Susannah-Prichard and the Jindyworobak poets), McLean rehearses a tired art-critical move in privileging the work of their 'radical modernist' contemporaries (e.g. Sidney Nolan, Albert Tucker and Max Harris). He writes: 'Even if ... we judge the achievements of these radical modernists as fatalistic and important, they did finally accept the failure of redemptive tropes in Australian discourses and picturings of identity and attempted to rethink what it was to be an Australian from this failure' (p 95). The fact that Australia's pioneering modernist artist and pre-eminent 'white Aborigine' was arguably Margaret Preston highlights gender as an important axis in any account of the relationship between Aboriginality and modernism in early twentieth century Australian culture. The inter-war avant-garde's 'rethinking' of Australian identity was inextricable from the attempt to 'redeem' modernism from the taint of its previous associations with the 'feminine' spheres of commercial art and interior design. I was left wondering why McLean fails to engage with the persuasive claims of feminist art historians that the history of Australian modernism has been re-written to emphasise the importance of male artists within the idiom's development. ${ }^{4}$

McLean's emphasis on 'radical modernists' also causes him to neglect the representation of Aborigines in the art of 'social realists' such as Yos1 Bergner and Noel Counihan. This is a significant omission because, in contrast to the 'fatalism' of their 'radical modernist' colleagues, these two artists elaborated on the messianic themes of Judeo-Christian and Marxist metanarratives. Bergner 
arrived in Melbourne in 1937 as a 17-year-old refugee from the Warsaw ghetto. His sensitivity to indigenous dispossession, expressed in paintings such as Aborigines in Fitzroy (1942) and Aborigines in Chains (1946), would have been heightened by the fact that his father had been to Alice Springs and the Kimberlys in 1934 looking for potential sites of Jewish settlement in Australia. And Counihan's linocut, [Albert] Namatjira (1959), made shortly after the artist's death, is more accusatory than melancholy. This work depicts the mission-educated Namatjira hanging on a cross elevated over a city-scape from which church spires erupt like the barbs of White Australian hypocrisy. When these artists are put into the picture it becomes clear that themes of 'exodus', 'sacrifice' and 'revolution' are as pertinent to an account of non-indigenous subjectivity as McLean's trope of melancholy/redemption.

Namatjira - the first indigenous artist to mimic European aesthetic conventions-provides a hinge for McLean's transition a focus on the 'The Aboriginal Renaissance'. He provides a reasonably thorough account of the political struggles over landrights and self-determination in the 1960s and 1970s from which the contemporary Aboriginal art movement emerged. It is at this point in his narrative that 'reconciliation' is posited as a way out of the colonial melancholy/redemption binary. He writes for example: 'Many urban Aboriginal artists also followed the path of reconciliation; their art often dealing with Aboriginal and non-Aboriginal Australian traditions ... In Aboriginal communities art was being made the broker for reconciliation - both between Aboriginal and non-Aboriginal values, and between tradition and change' ( $\mathrm{p}$ 109). McLean's implication that reconciliation is an indigenous initiative is misleading and fails to address the context of escalating racial tensions (e.g. the findings of the Royal Commission into Black Deaths in Custody in 1990 and anti-bicentennial protests in 1988) from which reconciliation emerged as a bipartisan government policy in 1991. Chapter Seven discusses the breed of 'White Aborigines' who came to prominence during the 1980s. Debates about the respective aesthetic and political agendas of postmodernis $m$ and postcolonialis $m$ are conscientiously surveyed and the appropriative practices of non-indigenous Australian artists are justified in the following terms: 'Despite its imperial overtones ... the concept of the white Aborigine does figure a desire for some form of reconciliation' ( $p$ 127). This is an unsatisfying response to accusations made by contemporary indigenous artists such as Fiona Foley, who is cited rather perfunctorily, that postmodern artists, such as Imants Tillers and Tim Johnson, are 'stealing from Aboriginal culture'.

In chapter Eight, McLean slides almost imperceptibly from the cynical suggestion that reconciliation with 'imperial overtones' is better than nothing at all, to a utopian vision of reconciliation as genuine cross-cultural rapprochement. The discussion of the contemporary indigenous artist, Gordon Bennett, is the obvious climax towards which the narrative has been propelling us: 'Gordon Bennett ... does not easily find a place in either Aboriginal or non-Aboriginal Australia. In finding a way of being between the two, he exceeds the binary logic of the colonial paradigm ... [His] quest to negotiate a subjectivity from within difference marks his artworks as exemplary icons of reconciliation' ( $p$ 145). McLean introduces Bennett's work with the following claim: 'Australia is still 
a colonial culture because it remains two worlds ... [a] two nation paradigm (henceforth called the colonial paradigm)' (p 134). I would strenuously dispute this characterisation and argue that Australian colonialism is more accurately described as a 'two worlds-one nation' paradigm. The persistent statutory force of terra nullius is evident in the fact that, even after the 1992 High Court Mabo decision which recognised Native Title, there have been no moves on the part of non-indigenous Australia to acknowledge the existence of distinct Aboriginal nations. This uneven distribution of sovereignty means that while it remains a 'life-style' choice for non-indigenous Australians, reconciliation is something that indigenous Australians are forced into to avoid subjective rupture. As Bennett puts it: "I was socialised to believe that the [Eurocentric] "I" included me, totally. When I discovered my Aboriginal descent I first denied and repressed it. When the repression became unbearable ... that was a true decentring ... almost of my entire system of belief - I mean a psychic rupturing' (p 146). This is a sense of subjective crisis echoed repeatedly in the stories recorded in the 1997 National Inquiry into the Separation of Aboriginal and Torres Strait Islander Children from Their Families. How is it that Bennett's attempt to avoid 'psychic rupturing' becomes for McLean a vision of reconciliation for 'a new republic'? McLean argues that: 'The mirror [in Bennett's iconography] is [his] window of opportunity by which to deconstruct the semiology of colonialism and, at the same time, refigure the differences which have sustained its power for so long. Living, like all of us, in a postmodern world [he] finds himself in an endlessly repeating mirrorama rather than gazing out the panoramic window of essentialist identities' ( $p$ 148). McLean's ability to absorb Bennett's project into a broader postmodern agenda made me wonder about the extent to which postcolonial reconstructions of subjectivity are effectively deconstructive of colonial subjectivity? In a postscript which functions as a receptacle for the theoretical debates that inform his text he writes: 'cultures behave like individuals ... the project of postcolonial art and criticism has all the markers of an Oedipal drama ... Not only is the subject far from home, but the indigenous culture which might offer shelter is made abject, and hence it is destroyed, yet preserved (repressed) in the psyche of the nation' ( $p$ 150). This highlights the extent to which McLean's take on Australian art is overdetermined by his identification with the Eurocentric subject of psychoanalytic theory. The melancholy/redemption trope, rather than 'mirroring' the structure of Australian colonialism, can be seen as a product of this identification.

That McLean personally gravitates towards the melancholy pole of the melancholy/redemption trope is apparent in the tone of resignation that pervades White Aborigines. Phrases such as: 'It was inevitable ...' (p 27), 'the imperatives of invasion ...' (p 27), 'This aim was entirely predictable' (p 28) and 'Hope vanishes like a mirage' ( $\mathrm{p}$ 166) abound. And, after criticising Paul Carter's 'migrantology' for offering redemption, he seals his case (and fate?) with the following line from A. D. Hope: 'The Rescue will not take place' ( $p$ 166). Perhaps my inability to respond to his melancholy is linked to my reading/ reviewing position as a queer, white feminist vis-à-vis the national psyche to which he refers. From this partial perspective, the proposition that 'cultures 
behave like individuals' is as phallocentric as it is Eurocentric and necessarily begs the question: 'Which cultures? Which individuals?'

Towards the end of his discussion of Gordon Bennett, McLean introduces the artist Tracey Moffatt in the following terms: 'Bennett is not the only Australian artist picturing a postcolonial subject in terms of a cross-cultural imagination. For example, Tracey Moffatt, of the same generation as Bennett, also proposes a postcolonial palimpsest of past and present ... As different as Bennett's and Moffatt's art is, they each problematise essentialist notions of Aboriginal and non-Aboriginal identitie s ...' (p 147). His reference to the fact that Bennett and Moffatt are 'the same generation' seems to be an attempt to evade confronting their different approaches to identity politics. While Moffatt consistently refuses the label 'Aboriginal artist' and demands recognition within the rarefied sphere of international auteurism, Bennett struggles to (re)claim his Aboriginality. Bennett's 'history paintings' aim to educate the viewer about the epistemological foundation s that structure white Australian perceptions of indigneity. In contrast, Moffatt has famously stated: 'As an artist I have never been on a mission to educate ... If people are racist, sexist, homophobic or out of step with issues I say bad luck! Let them stay dumb!' ${ }^{5}$ Moffatt is not an artist with whom a White academic can easily prove a point. Her highly stylised art-cinema, nude self-portraits with sheep and homoerotic photographic stills have a way of rebounding on the most serious critics. The only thing I would say with confidence is that her practice is marked by a refusal to conform to critical expectations of what a female indigenous artist is. ${ }^{6}$

At the end of chapter Eight, the deconstructive agenda of postcolonial art is inexplicably feminised by McLean: "Bennett and Moffatt hold up the broken mirror of coloniality to show that the other is there, that "she" is looking at us, and that we are all implicated in "her" gaze' ( $p$ 148). Perhaps it is Moffatt's refusal to 'settle' as an 'exemplary' postcolonial artist that simultaneously troubles the grammatical construction of this sentence and undermines its central (Lacanian) proposition. This textual rupture is valuable because it affords us a glimpse of a scopic regime that does not centre on the subject of psychoanalytic theory. It helps us to understand the dynamic which led the delegates at the 1997 national reconciliation convention to turn their backs on the Prime Minister, John Howard, after he refused to apologise to the stolen generation. Moments such as this - when the gaze of indigenous Australia is averted in absolute disgust - are reminders that the relationship between indigenous and non-indigenous Australians will have become postcolonial only when the gaze of the other has ceased to play a role in the constitution of the colonial subject. McLean's forcefully argued and thought-provoking book highlights the need for accounts that recognise that the invasive form of White Australian identity incubated by over two centuries of terra nullius is irreducible to psychoanalytic paradigms which take sexual difference as their point of departure.

\section{Notes}

Mabo v Queensland (No 2). 
2 For a transcription of the reasoning behind Judge Onley's decision see The Members of the Yorta Yorta Aboriginal Community $\mathrm{v}$ the State of Victoria \& Ors, http//www.austlii.edu/au/cases/cth/federal/-ct/1998/ 1606.html.

3 C E W Bean, 'Frontline Gallipoli', Kevin Fewster (ed.), Sydney, Allen \& Unwin, 1983, p 186.

4 For further elaboration of this position see Jeanette Hoorn, 'Women make modernism: contesting masculinist art criticism', in Strange Women: Essays in Art and Gender, Manchester University Press, 1994 and Caroline Jordon, 'Designing Women', Art and Australia, 31(2), 1993.

5 Correspondence between Tracey Moffatt and Claire Williamson, reprinted in Eyeline, Autumn, 1992, p 8.

6 See for example Adrian Martin, 'Tracey Moffatt's melodrama', World Art, 2, June 1995. 